\begin{tabular}{rr} 
çağdaş & Yaratıcı Drama Dergisi 2016, 11(2), 99-118 \\
drama & www.yader.org \\
\hline
\end{tabular}

\title{
Maddenin Yapısı ve Özellikleri Ünitesinde Yaratıcı Drama Yönteminin Kullanılması Üzerine Bir Uygulama Çalışması ve Öğrenci Görüşleri
}

\author{
Dr. Şahin İdin ${ }^{1}$
}

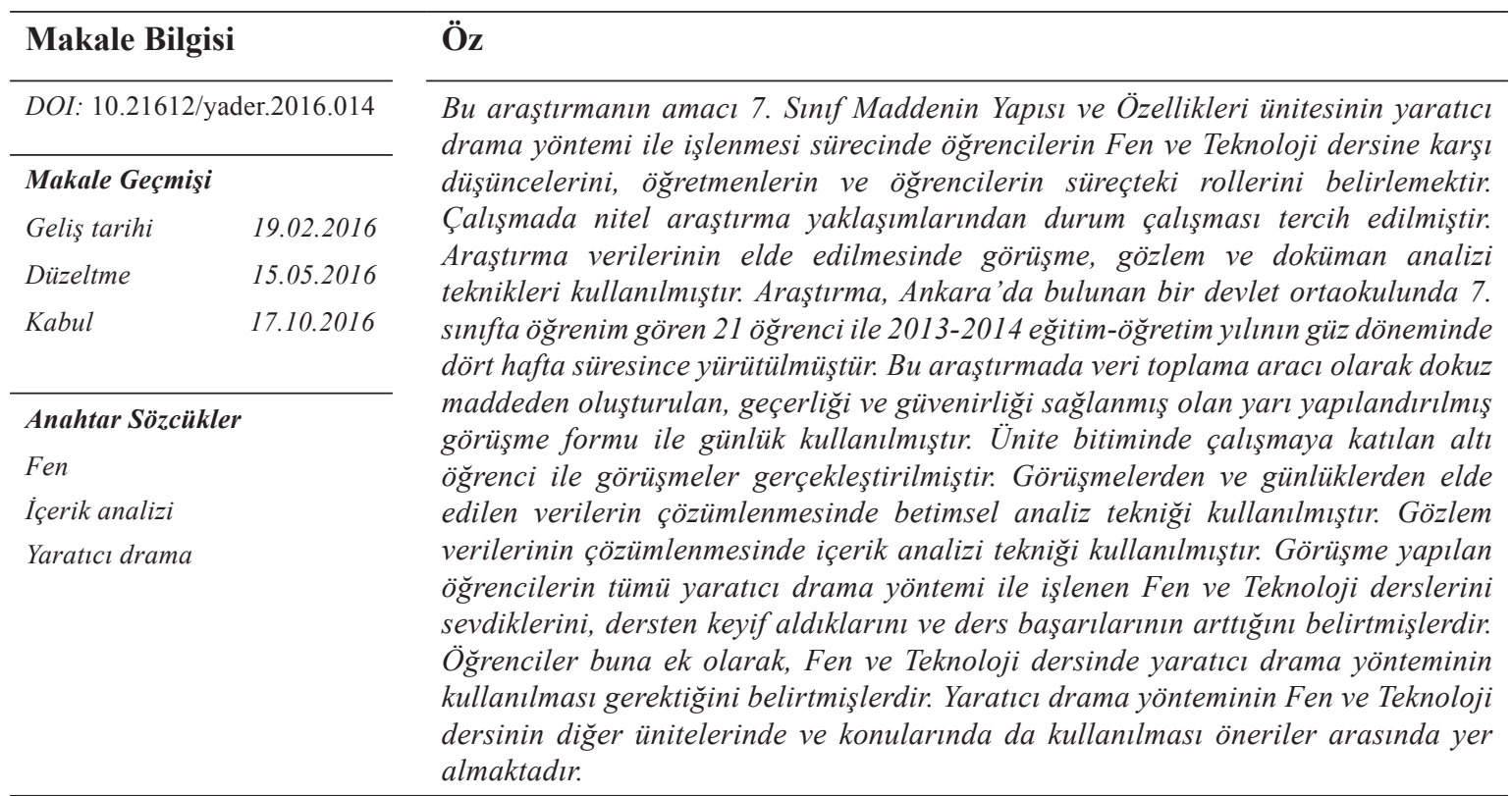

\section{The Implementation of Creative Drama Method and Students' Perceptions for the Unit of Matter's Structure and Characteristics}

\begin{tabular}{ll} 
Article Info \\
\hline DOI: $10.21612 /$ yader.2016.014 \\
\hline Article History & \\
Received & 19.02 .2016 \\
Revised & 15.05 .2016 \\
Accepted & 17.10 .2016
\end{tabular}

Keywords

Science

Content analysis

Creative drama

\begin{abstract}
The aim of this research is to specify of 7th grade students views which is taught the Matter's Structure and Characteristics unit within their Science and Technology course via using creative drama method. In the study, case study was chosen as one of the method of qualitative research approach. Interviews, observation and documan analysis techniques were used to get the research data. This study was carried out with twenty-one 7th grade state school students during four weeks in the 2013-2014 fall educational year, in Ankara. In this study, a semi-structured interview form was used, whose realibity and validity was provided, as a data tool which was created from nine items. Interviews were carried out, who joined the study, with six students when applications ended. Descriptive analyses technique was used to obtain data which were taken from interviews and diaries. Content analysis technique was used to obtain observational data. All of the students, who did interviews, specified that they liked science courses which were carried out via using creative drama, they enjoyed from the course and they told their course achivement has increased, as well. The students, in addition to this, specified that it is necessary to be used creative drama method in science courses. It is fall into among recommendations that to be used creative drama method both other units and issues in science courses.
\end{abstract}




\section{Giriş}

Fen ve Teknoloji dersinde öğrencilerin dünyayı anlamaları, fen-teknoloji-toplum-çevre arasındaki etkileşimi öğrenmeleri beklenmektedir (MEB, 2005). Bunun yanında Fen ve Teknoloji dersi açısından bireylerin fen okuryazarı olarak yetiştirilmeleri önemsenmektedir. National Research Council (NRC) (1996)'e göre fen okuryazarlığı; ekonomik üretkenlik, kültürel ve sivil olaylara katılım, bireysel kararlar verebilme için gerekli olan bilimsel kavramları ve yöntemleri bilme ve anlama olarak tanımlamıştır. MEB (2016), PISA projesi kapsamında okuryazarlık kavramını, öğrencilerin bilgi ve potansiyellerini geliştirip, topluma daha etkin biçimde katılarak katkı sağlaması için yazılı kaynak bulma, kabul etme ve değerlendirme olarak tanımlamaktadır. Bu bağlamda PISA'da 15 yaş gurubu öğrencilerin fen bilimleri, matematik ve okuma okuryazarlıklarına ilişkin veriler toplanmaktadır.

İleri toplum seviyesine ulaşabilmek için yeryüzündeki ülkeler eğitim sistemlerine yatırım yapmaktadırlar. Toplumların çağın gereklerine uygun olarak ilerlemesinde eğitimin etkisi bulunmaktadır (İdin, 2015). Çepni (2007)'ye göre fen eğitimi bir bütün olarak düşünüldüğünde toplumun tamamının ve gelecekteki insanlarımızın bilimsel okuryazarlık ihtiyacını karşılamalıdır. Böyle düşünüldüğünde, MEB, Fen Bilimleri dersinin yapısında zaman zaman değişikliklere gitmektedir. MEB (2013), Fen Bilimleri dersinde sorgulama temelli öğrenme yaklaşımı benimsenmiş ve dersin adını Fen Bilimleri olarak değiştirmiştir. Öğrencilerin dersi öğrenme sürecinde araştırma yapmaları ve öğrenme sürecinde edindikleri bilgileri sorgulamaları beklenmektedir.

Fen Bilimleri eğitimi, içerdiği konular ve diğer derslerle ilişkisi bağlamında kapsamlı bir disiplindir. Bu açıdan bakıldığında zaman içerisinde Fen Bilimleri dersinin öğretim süreçlerinde yeni yöntem ve tekniklerin kullanıldığı ve yeni programların geliştirildiği görülmektedir (MEB, 2000; MEB 2005; MEB 2013). Ders öğretmenlerinin değiştirilen öğretim programında yer alan yöntem ve teknikleri özümsemeleri ve kendilerini geliştirmeleri dersin öğretiminin verimli olmasında etkili olacaktır. Öğretmenlerin sahip olmaları gereken ve MEB (2016) tarafından belirlenen genel mesleki yeterliliklerin dersin verimli bir şekilde öğretimi ve öğrenciler tarafindan algılanmasında bir faktör olduğu düşünülmektedir. Özdemir ve Üstündağ (2007), öğretmenlerin öğretme ve öğrenme süreçlerine rehberlik ederken, birikimlerine göre davrandıklarını belirtmektedirler. Bunun yanında öğrenme ortamı ve öğretim süreçlerinde kullanılan yöntem ve teknikler öğrenmenin verimli olmasında önemlidir. İdin (2015)'e göre, tek başına bir öğrenme ortamından ziyade, zenginleştirilmiş eğitim uygulamalarının öğrenme süreçlerinde kullanılmalıdır.

2013 Fen Bilimleri Dersi Öğretim Programı'nda, dersin planlanmasında ve uygulanmasında, sorgulayıcı öğrenme yaklaşımı çerçevesinde; argümantasyon, probleme dayalı öğrenme ve proje tabanlı öğrenme ortamlarının sağlanması, öğrencinin aktif olduğu uygulamaların öğretim sürecinde temel alınabileceği belirtilmiştir (MEB, 2013). Bu açıdan bakıldığında yenilenen 2013 Fen Bilimleri Dersi Öğretim Programı ile birtakım yeni öğretim yöntem ve tekniklerinin kullanıldığı görülmektedir.

Üstündağ (1996) yaratıcı dramay1; bir öğretim yöntemi, sanat eğitimi alanı ve bir disiplin olarak bireylerin kendilerini rahat bir biçimde ifade edebileceklerini ve grup çalışmalarına açık olmalarını sağlayacak bir yaklaşım olarak tanımlamaktadır. Adıgüzel (2012), yaratıcı dramayı, bir grup ve grup üyelerinin yaşantılarından yola çıkarak, bir amacın, düşüncenin, doğaçlama, rol oynama, vd. tekniklerden yararlanarak, canlandırılması olarak tanımlamaktadır. Yaratıcı dramayı oluşturan çeşitli ögeler bulunmaktadır. Bunlar: yaratıcı drama eğitmeni, konu-tema, çeşitli teknikler, grup, yaşantı-tecrübe, oyunsu özellikler ve canlandırmadan oluşmaktadır (Adıgüzel, 2012). 
Talim Terbiye Kurul Başkanlığı (2012), Drama Dersi Öğretim Programı’nda dersin amaçlarını kısaca; yaratıcı olmanın hayatın her alanı için geçerli olması gerektiği, çocukların kendini rahat ifade edebilecekleri ortamı ve olanakları yaratmak gerektiği, eleştirel düşünme yetisinin geliştirilmesine katkıda bulunulması, birlikte bir fikir, bir durum üstüne tartışabilme şeklinde ortaya koymuştur.

Yaratıcı drama eğitim programı tamamlandığında; bireylerden, kendi özelliklerinin farkına varmaları ve bireysel farklılıkları ayırt edebilmeleri, grup üyelerini tanıyarak onlarla iletişim kurabilmeleri, empati kurabilmeleri, yaratıcı dramayla ilgili bilgi ve birikimini günlük hayatta kullanabilme ve yaratıcı dramanın toplumsal boyutunu vb. gibi hedeflere ulaşmaları beklenmektedir (Üstündağ, 2010).

Yaratıcı dramanın yöntem olarak kullanıldığı ilgili literatüre bakıldığında, fen ve teknoloji dersi kapsamında ortaokul öğrencileri ile gerçekleştirilen yaratıcı drama ile yapılmış akademik çalışmaların özellikle yüksek lisans ve doktora düzeyinde tez çalışmalarının sınırlı sayıda olduğu, Yüksek Öğretim Kurulu (YÖK) Ulusal Tez Merkezi'nin web sayfası verilerinden elde edilmiştir. Buna göre, Ulusal Tez Merkezi'nin web yaratıcı drama, fen ve teknoloji, fen bilimleri, anahtar kelimeler olarak yazılarak arama yapıldığında toplam 14 yüksek lisans tezinin ve bir doktora düzeyinde tez çalışmasının yapıldığı belirlenmiştir. Bir yüksek lisans tezinde 6. sınıf düzeyinde Maddenin Tanecikli Yapısı ünitesi kapsamında yapıldığı belirlenmiştir (YÖK Ulusal Tez Merkezi, 2016).

Tuncel (2009) ve Çopur (2014), yaratıcı dramayı yöntem olarak kullandıkları tez araştırmalarında, yaratıcı dramanın öğrencilerin fen ve teknoloji ders başarılarına etkisinin olup olmadığına bakmışlarıdır. Yaratıcı drama ile işlenen fen ve teknoloji derslerindeki öğrencilerin başarılarının kontrol grubundaki öğrencilere oranla ve ön test sonuçlarına göre fazla artış gösterdiğ $i$ sonucuna ulaşmışlardır. Yağmur (2010), altıncı sınıf öğrencileri ile Kuvvet ve Hareket Ünitesi kapsamında yaptı̆̆ öğrencileri ile kontrol grubu öğrencilerinin başarıları arasında anlamlı bir farklılık olmadığını ortaya koymuştur. Açıl (2012), fen ve teknoloji dersi kapsamında, yaratıcı drama yöntemini kullanarak dördüncü sınıf öğrencilerinin akademik başarılarındaki değişimi belirlediği çalışmasında, öğrencilerin kazanımların tamamında aynı başarı düzeyine ulaşamadıklarını belirlemiştir. Kimi kazanımların çok iyi anlaşıldığını kimi kazanımların ise öğrencilerce tam olarak anlaşılamadığını ortaya koymuştur. Bu araştırmalarda görüldüğü üzere yaratıcı dramanın yöntem olarak kullanıldığı bazı araştırmalarda, Fen ve Teknoloji derslerindeki kazanımlar kapsamında başarının tam olarak elde edilemediği sonucuna ulaşılmıştır.

İlgili literatür incelendiğinde, fen ve teknoloji dersi bağlamında, yedinci sınıflarda Maddenin Yapısı ve Özellikleri Ünitesi ile ilgili olarak gerçekleştirilmiş herhangi bir doktora tezine, yüksek lisans tezine ve doğrudan yaratıcı dramanın yöntem olarak kullanıldığı makaleye rastlanamamıştır. Bu araştırma ile 7. sınıflarda Fen ve Teknoloji dersi açısından Maddenin Yapısı ve Özellikleri Ünitesi kapsamında ilgili kazanımların öğretimi sürecinde bu eksikliğin giderilmesi hedeflenmiştir. Böyle düşünüldüğünde bu araştırma kapsamında ve yaratıcı drama yöntemi bağlamında hazırlanan ve geliştirilen etkinliklerin ve uygulamaların bu üniteye özgün olması ve ünite kapsamındaki kazanımlar dâhilinde özgün biçimde ve orijinal olarak geliştirilmesi, bu çalışmayı diğer araştırmalardan ayırmaktadır. Bunun yanında Maddenin Yapısı ve Özellikleri ünitesinde; atom, elektron, proton, yörünge vb. kavramlar bulunmaktadır. Bu ünite kapsamında öğrenilmesi zor olan soyut kavramların olduğu bilinmektedir. Bunun yanında öğrenciler bu ünite kapsamındaki kavramları 
öğrenme süreçlerinde kavram yanılgılarına düşebilmektedirler. Ayas ve Özmen (2002), lise 1 ve lise 2 öğrencileri ile gerçekleştirdikleri araştırmada, araştırmaya katılan öğrencilerin maddenin tanecikli yapısı kavramını anlama düzeylerinin düşük olduğunu belirlemişlerdir. Ürek ve Tarhan (2005), araştırmalarında öğrencilerin Maddenin Yapısı ünitesindeki, Kovalent Bağlar konusunda birçok kavram yanılgısına sahip olduklarını belirlemişlerdir. Bu kavramlar öğrencilere doğrudan gösterimi yapılamadığından, yaratıcı drama yöntemi kapsamında geliştirilen etkinlikler ve doğaçlamalar sayesinde öğrenilmesi zor olan kavramların daha kolay biçimde öğrenciler tarafından öğrenilmesi beklenmektedir. Yaratıcı drama yöntemi sayesinde, öğrenciler ünite kapsamındaki kavramları kendilerinin aktif olacakları etkinlikler, doğaçlamalar ve canlandırmalar vb. tekniklerle kavram yanılgılarına düşmeden öğrenmeleri beklenmektedir. Bu araştırma ile, ilgili ünitenin tamamında yöntem olarak kullanılan yaratıcı dramaya ilişkin öğrenci görüşlerinin belirlenmesi ve ileride yaratıcı dramanın yöntem olarak kullanılacağı araştırmalarda dikkat edilmesi gereken noktalara 1şık tutması beklenmektedir. $\mathrm{Bu}$ araştırmanın; Fen ve Teknoloji dersi kapsamında, yaratıcı drama yönteminin kullanılacağı akademik çalışmalarda ve sınıf içi uygulamalarda drama liderlerine, fen bilimleri öğretmenlerine ve akademisyenlere yol göstermesi ve bu ünitede yer alan kazanımların öğretim süreçlerinde öğrencilerin ilgili kazanımları öğrenmelerini pozitif yönde etkileyeceği düşünülmektedir.

$\mathrm{Bu}$ araştırmanın amacını, 7. Sınıf Maddenin Yapısı ve Özellikleri ünitesinin yaratıcı drama yöntemi ile işlenmesinin öğrencilerin fen ve teknoloji dersine karşı düşüncelerinin belirlenmesi oluşturmaktadır.

\section{Problem Cümlesi}

Araştırmanın problem cümlesi iki kısımda incelenmiştir. İlköğretim ikinci kademede öğrenim gören öğrencilerin yaratıcı drama yöntemi ile işlenen fen ve teknoloji dersine ilişkin görüşleri nelerdir? Proje çalışmalarına katılan öğretmen ve öğrencilerin süreçteki rolleri nelerdir?

\section{Alt Problemler}

1. Yaratıcı drama yöntemi ile işlenen fen ve teknoloji derslerine katılan öğrencilerin, sürece yönelik görüşleri nelerdir?

2. Yaratıcı drama çalışmalarına katılan öğretmen ve öğrencilerin süreç içerisindeki rolleri nelerdir ve öğrenci görüşme verileri ile öğrencilerin süreçteki rolleri uyuşmakta midir?

\section{Yöntem}

\section{Araştırmanın Modeli}

$\mathrm{Bu}$ çalışmada nitel araştırma yöntem olarak benimsenmiştir ve araştırma, nitel araştırma yaklaşımlarından durum çalışmasına uygundur. Durum çalışması, araştırmacının bir ya da çoklu sınırlandırılmış sistemlerde, keşfettiği bilgileri daha detaylı veri (gözlem, görüşme ve doküman) elde etmek için kullandığı bir nitel araştırma yaklaşımıdır (Creswell, 2007). Bir grup, birey ya da kurum çalışılan durumlara örnek teşkil edebilir. Araştırmalarda, nitel durum çalışmasının en temel özelliği bir ya da birkaç durumun bütüncül yaklaşımla incelenmesidir. Durum çalışması nitel araştırmada çok yaygın olarak kullanılan bir yaklaşımdır. Nitel araştırmalarda verilerin görüşme, gözlem ve doküman analizi gibi çeşitli şekillerde elde edilmesine çeşitleme (triangulation) denir (Yıldırım ve Şimşek, 
2011). Bu araştırmanın verilerinin elde edilmesinde görüşme, gözlem ve doküman analizi teknikleri kullanılmıştır. Öğrencilerle gerçekleştirilen görüşmelerin ve öğrencilere dağıtılan günlüklerden elde edilen veriler betimsel analize tabi tutulmuştur. Ders süreçlerinin gözlemlenmesinden elde edilen veriler içerik analizine tabi tutulmuştur. Gözlem verileri belirlenen temalar altında, kodların belirlenerek frekanslarının verilmesi ile tablolarda ortaya konmuştur.

\section{Çalışma Grubu}

Araştırma, 2013- 2014 eğitim- öğretim yılı güz döneminde, Ankara ili, Keçiören ilçesinde bulunan bir devlet ortaokulunda 7. sınıfta öğrenim gören 21 öğrenci ile yürütülmüştür. Araştırma, ilgili eğitim öğretim yılının güz döneminde dört haftada tamamlanmıştır.

\section{Veri Toplama Araçları}

Çalışmada veri toplama aracı olarak dokuz maddeden oluşturulmuş yarı yapılandırılmış görüşme formu (Ek 2), gözlem kayıtları ve öğrenci günlükleri kullanılmıştır. Öğrencilerin, yaratıcı drama yöntemi ile işlenen fen ve teknoloji dersine ilişkin düşünceleri belirlenmeye çalış1lmıştır. Görüşme formu oluşturulma sürecinde iki fen ve teknoloji dersi öğretmeninin, formda yer alan soruların öğrenci seviyesine uygun olup olmadığı ile ilgili görüşleri alınmıştır. Öğretmenlerin dönütleri sonrasında formda yer alan sorular üzerinde gerekli düzeltmeler yapılmıştır. Sonrasında görüşme formu alanında uzman iki akademisyen tarafından incelenmiştir. Alan uzmanlarından gelen geri bildirimler sonrasında görüşme formuna son hali verilmiştir. Bunun yanında uygulamaya katılan öğrencilerden, altısı ile gönüllülük esasına dayalı olarak, görüşmeler gerçekleştirilmiştir. Öğrencilerle derslerde yaratıcı drama yöntemi ile gerçekleştirilen çalışmalar, öğrenci velileri ve okul idaresinden izin alındıktan sonra, video-kayıt cihazı ile kayıt altına alınmıştır. Yaratıcı drama ile gerçekleştirilen fen derslerine ilişkin öğrencilerin düşüncelerini ve duygularını belirlemek için öğrencilere günlükler dağıtılmıştır. Öğrenci günlükleri ünite bitiminde öğrencilerden toplanmıştır.

\section{Verilerin Analizi}

Araştırmanın verilerinin çözümlenmesinde betimsel analiz ve içerik analizi teknikleri kullanılmıştır. Araştırmaların görüşmelerden ve günlüklerden elde edilen verileri betimsel analize tabi tutulmuştur. Betimsel analiz tekniğine göre (Yıldırım ve Şimşek, 2011), görüşülen ya da gözlenen bireylerin görüşlerini çarpıcı bir biçimde yansıtmak için sık sık doğrudan alıntılara yer verilmiştir. Görüşme verileri alan uzmanları tarafından incelenerek birbirinden bağımsız olacak biçimde kodlar ve temalar oluşturulmuştur. Elde edilen kodların ve temaların güvenirliğini ortaya çıkarmak için Miles ve Huberman'ın (1994), önerdiği “uyum yüzdesi” formülü kullanılarak güvenirlik değeri hesaplanmıştır. Uyum yüzdesi= (Uzlaşma)/(Uzlaşma+Uzlaşmama)X100 biçiminde formüle edilmektedir. Buna göre araştırmalardaki uyum yüzdesinin 70 ve üstü olması durumlarında görüşme verilerinin kullanılabileceği belirtilmektedir (Yıldırım ve Şimşek, 2008). Bu araştırma kapsamında görüşme formundaki uyum yüzdesi 88,40 bulunmuştur. Bu sonuç görüşme formunun uygun olduğunu ortaya koymaktadır.

Araştırmanın gözlem verileri içerik analizine tabi tutulmuştur. Bunun için gözlemlenen ortam, öğretmenin ve öğrencilerin süreçteki roller kapsamında ve araştırmanın alt problemlerine göre temalara ayrılmıştır. İlgili temalara araştırmanın bulgular bölümünde detaylı yer verilmiştir. Belirlenen temalar eşliğinde elde edilen veriler frekans ve yüzde olarak verilmiştir. 


\section{Araştırmanın Güvenirlik ve Geçerliği}

Araştırmanın geçerliği için iç geçerlik ve dış geçerlik kavramları göz önünde bulundurularak ilgili düzenlemeler gerçekleştirilmeye çalışılmıştır. Merriam (2009), nitel araştırmalar konusunda tartışan birçok yazar, nitel araştırmaların; paradigmaların felsefi varsayımları ile uyumlu bakış açıları eşliğinde geçerlik ve güvenirliği dikkate almasının gerekliliğini belirtmektedirler. Bulgular dikkatle incelendiğinde elde edilen verilerin anlamlı olduğu ve bir bütünsellik taşıdığı görülmektedir. Elde edilen bulguların kavramsal çerçeve ile uyumlu olduğu görülmüştür. Araştırmaya katılan katılımcılar ortaokul yedinci sınıfta öğrenim gören öğrencilerdir. Öğrenciler ilköğretim I. kademenin 4. sınıfindan itibaren, ünite kapsamındaki bu konuları işlemektedirler. Bu bağlamda öğrenciler, ünitede yer alan atom, madde, kimyasal değişim, bileşik vb gibi diğer kavramlara yabancı değildirler. Dolayısı ile gerçekleştirilen yaratıcı drama atölye çalışmaları ile araştırmanın gerçekçi bulunduğu katılımcılar tarafindan görüşmelerden elde edilen verilere göre teyit edilmiştir. Araştırmanın dış geçerliğinin sağlanması için; çalışma ortamının ve öğretim süreçlerinin başka örnekler ile karşılaştırma düzeyleri, araştırmanın genelleme amacı taşıyıp taşımadığı, ortamın ve kavramsal çerçevenin seçimi, çeşitlendirilme durumları ve olası genelleme durumları açılarından incelenmiştir. Bu bağlamda bu araştırma nitel türde olduğundan genelleme kaygısı taşımamaktadır. Bu araştırmada verilerin elde edilmesinde çeşitleme yapılarak zengin ve derinlemesine veri elde edilmiştir. Böylelikle araştırmanın kendi bütününde tutarlı olması ve araştırmanın kendi içerisinde bütünsellik taşıması sağlanmıştır.

Nitel çalışmalarda amaç genelleme yapmak değildir (Yıldırım ve Şimşek, 2011). Nitel araştırmalarda çalışmanın geçerli ve güvenilir olabilmesi için uzman görüşleri önemlidir. $\mathrm{Bu}$ kapsamda, araştırmada çalışma grubunun yeterli olup olmadığının belirlenmesi için iki alan uzmanının görüşüne başvuru yapılmıştır. Uzmanların analizi sonucu çalışma grubunun yeterli olduğu yönünde gerekli olan dönütler alınmıştır. Araştırma nitel türde bir araştırma olduğundan, araştırma genelleme gibi bir kaygı taşımamaktadırlar. Hatch (2002), araştırma soruları bir nitel araştırmanın oluşturulmasında ve yapılandırılmasında araştırma sorularını tanımlama kritik bir adımdır. Araştırma sorularının durum çalışmalarının felsefik paradigması ile uyumlu olacak şekilde hazırlanmasına çalışılmıştır. Nitel araştırmalar yapılandırılırken, bir nitel araştırma planında araştırma soruları önemli bir yer tutmaktadır (Creswell, 2007). Çalışma grubunun büyüklüğü ve kavramsal çerçeve düşünüldüğ̈̈nde, yapılan araştırmanın genelleme etkileri bulunmamaktadır. Araştırmanın bütününde süreç önemli olduğundan, burada belirli tanımlamalara yer verilmiştir. Bu araştırma boyunca, katılımcılar ile görüşmeler yapıldığından, belirli tanımlamalar yer almaktadır. Araştırmanın geçerliğ 1 sağlandıktan sonra güvenirliğin sağlanmasına çalışılmıştır. Nitel araştırmalarda kaliteyi artırmak için sonda sorular ve hazırlanabilir ve çeşitleme kullanılabilir (Yıldırım, 2010). Bunun yanında araştırmacı, katılımcılara sorduğu soruları farklı şekillerde belirtebilir ve bu kapsamda alternatif sorular hazırlayabilir (Miller, 1994; Shenton, 2004). Bu araştırmanın güvenirliği artırmak için, araştırma soruları, sondalar, alternatif sorular hazırlanmış ve farklı yollarda (gözlem, görüşme ve doküman analizi) veri toplanmıştır. Araştırmanın objektif olabilmesi açısından öğrencilerin sorulara verdiği yanıtlar, araştırmanın bulgular kısmında aynen verilmiştir. Bu bağlamda araştırmada farklı öğrencilerin aynı sorulara ait verdikleri farklı görüşlere yer verilmeye çalışılmıştır. Araştırmada ses kayıt cihazı ve video kayıt cihazı kullanılmıştır.

\section{Uygulama Planı}

Araştırmanın dört haftalık bir süreç sonunda tamamlanması planlanmıştır. Araştırmada Madde'nin Yapısı ve Özellikleri ünitesi ile ilgili olarak toplam 23 kazanım (Ek 3) verilmeye çalışılmıştır. Ünitenin öğretimi sürecinde, fen ve teknoloji derslerinde yöntem olarak yaratıcı drama kullanılmıştır. 
Bu kapsamda, Element ve Sembolleri konusu içerisinde yer alan kazanımlar (1.1, 1.2, 1.3, 1.4 ve 1.5) iki atölyede (2+2 saat), Atomun Yapısı konusu içerisinde yer alan kazanımlar (2.1, $2.2,2.3,2.4$ ve 2.5$)$ iki atölyede (2+2 saat), Katma-Elektron Dizilimi konusu içerisinde yer alan kazanımlar (3.1, 3.2, 3.3, 3.4 ve 3.5, 3.6 ve 3.7) iki atölyede (2+2 saat), Bileşikler ve Formülleri konusu içerisinde yer alan kazanımlar $(5.1,5.2,5.3)$ bir atölyede (2 saat) ve Karışımlar konusu içerisinde yer alan kazanımlar $(6.1,6.2,6.3)$ bir atölyede (2 saat) gerçekleştirilmiştir. Buna göre çalışma grubunda yaratıcı drama yöntemi ile ders işlenen gruplar 23 kazanımı toplam dört haftada (8 yaratıcı drama atölyesi) almışlardır. Haftada dört saat fen ve teknoloji dersi bulunmaktadır. İkişer saat olarak belirlenen derslerde ikişer atölye olacak şekilde yaratıcı drama yöntemi kullanılmıştır.

Ek (1)'de 1.1 ve 1.2 kazanımları için hazırlanmış örnek bir yaratıcı drama atölye ders planı görülmektedir. Süreç boyunca ilgili kazanımların bütünü için yaratıcı drama atölyelerinde ders planları hazırlanmıştır. İlgili ders planlarını, öncelikle alanda görev yapmakta olan iki fen ve teknoloji dersi öğretmeni incelemiştir. Öğretmenlerin ilgili ders planlarını fen ve teknoloji dersi ve kazanımların uygunluğu açısından incelemişlerdir. Öğretmenlerden gelen dönütlerden sonra ilgili düzeltmeler yapılmıştır. Sonrasında, ilgili ders planları yaratıcı drama alanında eğitim almış iki uzmana gönderilmiştir. Alan uzmanlarının dönütleri sonrasında ders planları üzerinde gerekli değişiklikler ve düzenlemeler yapılarak, ders planları oluşturulmuştur. Dersin kazanımları, ilgili kavramlar ve anlaşılırlıklar açısından öğretmenlerin belirttikleri eksiklikler göz önüne alınarak ders planları yeniden düzenlenmiştir. Sonrasında, ders planları için iki uzmanın görüşü alınmıştır. Uzmanlardan gelen dönütlere göre ders planları şekillendirilmiş ve ilgili yaratıcı drama atölyeleri yürütülmüştür.

\section{Bulgular}

$\mathrm{Bu}$ bölümde öğrenciler ile gerçekleştirilen görüşmelere, günlüklerde belirtilen düşüncelere ve yaratıcı drama çalışmalarının gerçekleştirildiği mekândan elde edilen bulgulara yer verilmiştir.

\section{Alt Probleme Yönelik Bulgular}

$\mathrm{Bu}$ kapsamda öğrencilere yöneltilen sorulardan ve günlüklerden elde edilen bulgular bu bölümde yer almaktadır.

\section{Okulunuzda uygulanan yaratıcı drama çalışmalarına daha önce katıldınız mı?}

Çalışmaya katılan öğrencilere, yaratıcı drama kapsamında hangi tür çalışmalara katıldıkları sorulmuştur. Görüşmeye katılan öğrencilerin tamamı $(\mathrm{n}=6)$ öğrenimleri süresince ilk kez yaratıc1 drama yöntemi ile ders işlediklerini belirtmişlerdir. Öğrenciler "Maddenin Yapısı ve Özellikleri Ünitesi” kapsamında bu çalışmaya katıldıklarını belirtmişlerdir. Ö1, Ö3 ve Ö5 kodlu öğrenciler "elektronlar, protonlar ve nötronlar" isimli konuların, Ö2 kodlu öğrenci "elektron sayısl, proton sayısı, nötron sayısı, elementler ve bileşiklerin" isimli konuların işlendiğini ve Ö6 kodlu öğrencide "atomlar, elemenler ve bileşiklerin" isimli konuları işlediklerini belirtmiştir.

\section{Derslerin yaratıcı drama yöntemi ile işlenmesinin nedeni ne olabilir?}

Öğrencilere fen ve teknoloji derslerinin bu şekilde işlenmesinin amacının ne olabileceği sorulmuştur. Ö1 ve Ö2 kodlu öğrencilerin yanıtları "konuları daha iyi anlamalarının ve kavramalarının sağlanması", Ö3 kodlu öğrencinin yanıtı "derslerin daha zevkli ve eğlenceli işlenmesi” Ö4, Ö5 ve Ö6 kodlu öğrencilerin yanıtları "dersin daha eğlenceli hale getirilip, daha kalıcı olarak, ögrenmenin öğrenci açısından daha kolay olmasının sağlanması" şeklindedir. 


\section{Sizce yaratıcı drama ile işlenen derslerin temel amacı ne olmalıdır?}

Ö1, Ö2 ve Ö6 kodlu öğrenciler, dersin yaratıcı drama yöntemi ile işlenmesinin temel amacı olarak fen derslerini daha iyi anlamak ve öğrenmek olduğunu belirtmişlerdir. Bunun yanında ders konularının daha basit bir düzeyde anlatımının sağlanmasının yaratıcı dramanın amaçları arasında olması gerektiğini belirtmişlerdir. Ö3 kodlu öğrenci, yaratıcı drama yönteminin amacının fen derslerinin öğretimi süresince, "ders sürecinde öğrenciler arasında daha iyi iletişim kurmak" olması gerektiğini vurgulamıştır. Ö4 ve Ö5 kodlu öğrenciler yaratıcı drama yönteminin amacının “dersin daha ĕglenceli, neşeli ve güzel işlenmesini sağlaması gerektiğini” belirtmişlerdir. Bunun yanında bu öğrenciler, yaratıcı drama yöntemi ile işlenen derslerden sonra öğrencilerin evlerine daha mutlu gitmeleri gerektiğini belirtmişlerdir. Bu açıdan düşünüldüğünde, yaratıcı dramanın böyle bir amacının da olması gerektiğini belirtmişlerdir.

\section{Katıldı̆̆ınız yaratıcı drama çalışmalarında kullanılan teknikleri nasıl buluyorsunuz?}

$\mathrm{Bu}$ soru ile öğrencilere yaratıcı drama yöntemi kapsamında kullanılan teknikleri nasıl değerlendirdikleri sorulmuştur. Ö1 kodlu öğrenci yaratıcı drama yöntemi süresince kullanılan teknikleri "bu tekniklerin dersleri daha iyi anlamasına yardımcı olduğunu, süreçte gelişen iletişim sayesinde konuları algılamasının arttı̆̆ını ve dersin daha iyi işlenmesini sağladığını" belirtmiştir.

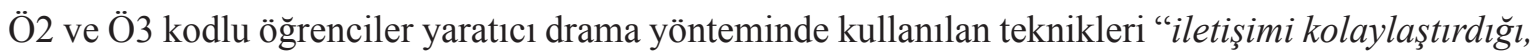
kullanılan tekniklerin sıra dışı olduğunu, yardımlaşmayı sağladı̆̆ını” belirtmişlerdir. Ö4 kodlu öğrenci kullanılan teknikler sayesinde "öğrenmenin eğlenceli olarak gerçekleştiği, konuları hatırlamasının daha kolay olduğunu ve fen derslerinde hikâyeler yazmaya başladığını" belirtmiştir. Ö5 kodlu öğrenci hikâye yazmalarını ve bunu paylaşmalarını ve öğrenmenin bu sayede gerçekleştirilmesinin sağlanması açısından yaratıcı drama yönteminde kullanılan teknikleri sevdiğini belirtmiştir. Ö6 kodlu öğrencide kullanılan tekniklerin ders öğretmenin verdiği yönergeler sayesinde dersin daha güzel geçmesini sağladığını belirtmiştir.

Öğrenci günlüklerinden elde edilen veriler aşağıya aynen aktarılarak, bazılarına örnek olarak yer verilmiştir.

Sevgili günlük, Bugün ilk iki saat fen ve teknoloji dersiydi. Bugün derste yaratıcı drama ile fen ve teknoloji dersini işledik. Bugün derste etkinlikler yaptık ve oyunlar oynadık. Dersimiz yaratıcı drama sayesinde çok güzel geçti. fen ve teknoloji dersini sevmeye başladım....(07.01.2014-Öğrenci 12)

Bugün fen ve teknoloji dersinde çok eğlendim ve ders güzel geçti. Meyve sepeti adında bir oyun oynadık. Iyon, katyon ve anyonun ne olduklarını öğrendim. Birde arkadaşlarımla grup olarak doğaçlamalar yaptı. Umarım fen derslerinde hep bunun gibi oyunlar ve doğaçlamalar sayesinde ögrreniriz. Çünkü hem ĕgleniyoruz hem de ögreniyoruz... (10.01.2014-Öğrenci 16)

\section{Yaratıcı drama için kullandığını materyalleri nasıl değerlendiriyorsunuz?}

Görüşmeye katılan öğrencilerin tamamı $(n=6)$ ders süresince kullanılan malzemelerin basit yapıl1, bulunmalarının kolay olduğunu belirtmişlerdir. Ders süresince; karton, fon karton, bant, tahta kalemler, makas, kâğıt, boya kalemleri, kostümler vb. gibi eşyaların kullanıldığını tüm öğrenciler belirtmişlerdir. Ö6 kodlu öğrenci, kendisinin görsel olarak daha iyi öğrendiğini bundan dolay1, derste materyal kullanımının öğrenmesini olumlu yönde etkilediğini belirtmiştir. Ö2 kodlu öğrenci sahip 
oldukları basit materyaller ile konuların öğrenilmesi sürecinde yeni ve farklı şeyler ürettiklerini bunun da kendisinin fen derslerini daha çok sevmesini sağladığını belirtmiştir. Ö3 ve Ö4 kodlu öğrenciler ders sürecinde kullanılan materyallerin kırtasiyelerde kolayca bulunabilecek ürünler olduğunu belirtmişlerdir. Ö5 ve Ö6 kodlu öğrenciler, kullanılan materyallerin, fen laboratuvarlarında bulunabilecek, pahalı olmayan materyaller olduğunu belirtmişlerdir. Kullanılan materyallerin öğrenmelerine yardımcı olduklarını özellikle soyut kavramları anlamalarında etkili olduklarını belirtmişlerdir.

Öğrenci günlüklerinden elde edilen veriler aynen aktarılarak aşağıda bazılarına örnek olarak yer verilmiştir.

Bugünkü dersimizi yine yaratıcı drama eşliğinde işledik. Yaratıcı dramada derslerimizde hep malzemelerle işliyoruz. Karton, boyalar, kalemler, kağıtlar ve bant gibi malzemeleri kullanarak yeni şeyler üretiyoruz hem de öğreniyoruz.... (15.01.2014-Öğrenci 21)

Yaratıcı drama atölyesindeki çalışmalarda öğrendiğiniz yeni bilgilerden fen ve teknoloji derslerinde nasıl yararlanıorsunuz?

Ö1 kodlu öğrenci "sınavlarda yaratıcı drama anında işlenen derslerde yaptıkları aklına geldiğini ve böylece konuları ve kavramları hemen hatırladığını ve ders sonlarında öğrendiklerini eve gittiğinde düşündüğünü”; Ö2 kodlu öğrenci “elektronları nasıl oluşturduklarını düşündüğünde konuyu daha iyi anladı̆̆ını ve kolay hatırladığını, kitaba bakmadan ve ezber yapmadan konuyu hatırladı̆̆ını"; Ö3 kodlu öğrenci yaratıcı drama dersindeki çalışmalardan sonra öğrendiklerini "unutmadığını" belirtmiştir. Ö4 ve Ö6 kodlu öğrenciler ders sürecinde gerçekleştirdikleri canlandırmalar sayesinde ünitede yer alan konu ve kavramları unutmadıklarını ve anlamalarına yardımcı olduğunu belirtmişlerdir. Ö6 kodlu öğrenci derste öğrendiklerini sınavlarda ve uygulamalı etkinliklerde daha kolay transfer edebildiğini ifade etmiştir.

Fen ve teknoloji ders başarınızda, yaratıcı drama yöntemi ile ders konularını işledikten herhangi bir değişim oldu mu? Olduysa açıklar mısınız?

Görüşmeye katılan öğrencilerin tamamı $(n=6)$ bu soruya, yaratıcı drama yöntemi ile dersi işledikten sonra, ünite kapsamındaki konuları daha kolay ve iyi anladıklarını, Fen ve Teknoloji dersini daha çok sevmeye başladıklarını, dersin eğlenceli olduğunu, başarılarına olumlu etkilerinin olduğunu, diğer dersleri öğrenmelerinde de olumlu etkileri olduğunu, belirtmişlerdir. Ö1, Ö4 ve Ö6 kodlu öğrenciler yaratıcı drama yöntemi ile dersin işlendikten sonra fen bilimleri dersi sınav puanlarında artış olduğunu; Ö2 kodlu öğrenci yaratıcı drama yönteminden sonra derslerdeki performansının arttığını ve derse katılmaya başladığını; Ö3 kodlu öğrenci ders notlarının çok yükseldiğini ve artık arkadaşları ile birlikte bir araya geldiklerinde yaratıcı drama sayesinde öğrendikleri uygulamalar eşliğinde etkinlikler yaptıklarını belirtmişlerdir.

Öğrenci günlüklerinden elde edilen veriler aynen aktarılarak aşağıda, bazılarına örnek olarak yer verilmiştir.

Fen ve Teknoloji dersimin sınav puanlarımda Yaratıcı drama yöntemi sayesinde çok artış oldu. Eskiden ders puanlarım hem düşüktü hem de dersi sevmiyordum. Derste çok slkllyyordum. Derste öğretmenimiz soru sorduğunda söz hakkı almıyor ve derse katılmıyordum. Yaratıcı dramadan sonra çok şey değişti. Dersi isteyerek dinlemeye başladım. Ödevlerimi yapmaya başladım. Hem de yazılı notlarım yükseldi....(16.01.2014-Öğrenci 19) 
Sevgili günlük, bugünkü dersimizde rol oynadık. Kostümler giydik ve düşüncelerimizi resim şeklinde çizdik. Bugünkü dersimizde yine söz aldım. Doğaçlamalara katıldım. Dersten sonra, ögretmenimiz yanıma gelerek, dersteki performansımın bu dönem iyi olduğunu söyledi. Bu beni çok mutlu etti. Iyi ki ögretmenimiz bu dönem yaratıcı drama yöntemi ile bu üniteyi işledi... (16.01.2014-Öğrenci 07)

Fen ve teknoloji dersini daha önce hiç sevmiyordum. Çünkü dersteki konular çok sıkıcıydı ve anlamıyordum. Ancak bu ünitede daha önce karşılaşmadığımız yaratıcı drama ile konuyu işledik. Derste maddenin yapısını öğrenirken doğaçlamalar yaptık, oyunlar oynadık. Bunu ünitenin tamaminda yaptık. Ikinci haftadan itibaren fen dersine karşı olumsuz tavrım değişmeye başladı. Derste daha fazla söz almaya başladım. Öğretmenimizin ünite sonunda yaptığı sınavda daha önceki fen derslerinde hiç alamadı̆̆ım 72 puanı aldım...(16.01.2014-Ö̆̆renci12)

\section{Yaratıcı drama yöntemi ile ders işlemenin diğer derslere olan etkilerini nasıl değerlendiriyorsunuz?}

Görüşmeye katılan öğrencilerin tamamı $(n=6)$ bu soruya olumlu yanıt vermişlerdir. Ö1 ve Ö2 kodlu öğrenciler süreci yararlı bulduklarını ifade etmişlerdir. Ö2 kodlu öğrenci, yaratıcı drama yönteminden sonra diğer derslerinin daha iyi olduğunu belirtmiştir. Ö3 kodlu öğrenci, diğer derslere katılımının arttığını artık derslerde heyecanlanmadan ve utanmadan düşüncelerini daha rahat ifade edebildiğini belirtmiştir. Ö6 kodlu öğrenci, yaratıcı drama yönteminin diğer derslerde de kullanılması gerektiğini belirtmiştir. Buna neden olarak da diğer derslerde de anlayamadığı konular olduğunu ifade etmiştir. Örnek olarak sosyal bilgiler dersindeki tarihsel konuları hiç anlamadığını ancak bu dersteki konuları öğrenmede yaratıcı drama uygulamalarından canlandırmanın kullanılması halinde bu durumun dersi anlaması için çok iyi olacağını belirtmiştir.

Öğrenci günlüklerinden elde edilen veriler aynen aktarılarak aşağıda bazılarına örnek olarak yer verilmiştir.

Bugün Maddenin Yapısı ve Özellikleri Ünitesini bitirdik. Bu ünitede yaratıcı drama sayesinde hem dersi sevmeye başladım hem de ders başarım arttı. Diğer derslerde böyle etkinlikler yapmıyoruz. Keşke diğer derslerimizde de yaratıcı drama yöntemine uygulasak. Mesela, doğaçlamalar yapsak, meyve sepeti oyununu oynasak. ....(08.01.2014-Öğrenci 18)

Sizin, yaratıcı drama yöntemi ve bu şekilde ders işleme ile ilgili belirtmek istediğiniz herhangi bir düşünceniz var mıdır? Varsa dinleyebilirim.

$\mathrm{Bu}$ soru öğrencilerin yaratıcı drama yöntemine ilişkin düşüncelerini genel olarak anlamak için sorulmuştur. Ö1 kodlu öğrenci yaratıcı drama yöntemi için "her yerde, her derste, her zaman kullanılması gerektiğini düşünüyorum" şeklinde düşüncesini belirtmiştir. Ö2 kodlu öğrenci de Ö1 kodlu öğrenci ile aynı fikirde olduğunu buna neden olarak da öğrencilerin daha fazla fikir alış-verişinde bulanabildiklerini ifade etmiştir. Ö2 kodlu öğrenci ayrıca, yaratıcı dramanın tüm okullarda uygulanmasını gerektiğini belirtmiştir. Ö3 kodlu öğrenci yaratıcı dramanın, kendilerine çok yardımcı olduğunu, öğretmenleri ile daha rahat iletişim kurduklarını ve öğretmenlerine daha saygılı davranmaya başladıklarını, belirtmiştir. Ö4 kodlu öğrenci, tüm fen derslerinde yaratıcı drama yönteminin kullanılması gerektiğini buna gerekçe olarak da öğrenmelerinin daha eğlenceli olduğunu, belirtmiştir. Ö5 ve Ö6 kodlu öğrenciler diğer derslerde de yaratıcı drama yönteminin kullanılması gerektiğini buna gerekçe olarak da diğer derslerde sıkıldıklarını ifade etmişlerdir. Bunun yanında arkadaşlarının diğer derslerde, dersin akışını bozmaya çalıştıklarını ancak yaratıcı drama etkinlikleri sayesinde bu durumun oluşmadığını ifade etmişlerdir. 


\section{Alt Probleme Yönelik Bulgular}

Araştırmanın ikinci alt problemine yanıt verebilmek için yaratıcı drama uygulamalarının gerçekleştirildiği mekân içerisinde yapılan gözleme ilişkin veriler toplanmış ve bu veriler yorumlanmıştır. Araştırmanın gözlemleri sırasında bir video-kayıt cihazı kullanılmıştır. Nitel araştırmalar konusunda tecrübeli ve gözlem sürecinde dikkat edilmesi gereken hususları bilen diğer bir eğitim uzmanı, video-kayıt cihazı ile çalışmanın yürütüldüğü ortamı gözlemlemiştir. Her bir gözlem 40 dakika sürmüştür. Çalışmanın yapıldığı ortam bir sınıftır. İlgili sınıf yaratıcı drama çalışmalarına uygun hale getirilmiştir. Mekânın yapısı, öğretmen ve öğrencinin süreçteki rolü, tematik kodları altında araştırmanın ikinci alt problemine ilişkin bulgular elde edilmiştir.

\section{Mekânın yapısı:}

Yaratıcı drama çalışmalarında mekân sürecin verimli olması anlamında önemlidir. $\mathrm{Bu}$ kapsamda yaratıcı drama çalışmalarının yapıldığı mekânın fiziki durumunu anlatmak gerekli görülmektedir. $\mathrm{Bu}$ araştırma sürecinde yaratıcı drama çalışmalarının yürütüldüğü sınıfı ele aldığımızda; sınıfta toplam 11 sıra ve 11 masa bulunduğu belirlenmiştir. Mekân yapısı itibariyle orta büyüklükte bir sınıftır. Çalışılan ortamda dikkat dağıtıcı nesnelerin olmayışı çalışmaların verimini artırabileceği söylenebilir. Atölyeler sürecinde, öğretmenin öğrencilere yaklaşımı ve öğrencilerin kendi aralarındaki iletişimin olumlu olduğu belirlenmiştir. Yaratıcı dramanın yöntem olarak kullanıldığı mekânın atölyelerin gerçekleştirilmesi için uygun olduğu gözlemlenmiştir. Öğrencilerin uygulamalar sırasında zarar görmesinin önüne geçmek için mekânda bulunan sıra, masa gibi malzemelerin mekanda bulundurulmadığı gözlemlenmiştir. Mekân çalışmaları dikkate alındığında yaratıcı drama sürecini yürüten öğretmenin rolü ve öğrencilerin rolü araştırmanın etkililiği açsından önemlidir.

\section{Öğretmen ve öğrencilerin süreçteki rolleri:}

Öğretmenlerin ve öğrencilerin yaratıcı drama çalışmalarını gerçekleştirirken, süreçteki rollerine ve gerçekleştirilen uygulamaların türüne ilişkin bilgiler Tablo 1'de sunulmuştur.

Tablo 1. Öğretmen-Öğrencilerin Süreçteki Rolleri ve Uygulamaların Türü Açısından Gözlem Kodlarının Frekanslarını Gösteren Veriler

\begin{tabular}{llcc}
\hline $\mathbf{f}$ & Öğretmenin Süreçteki Görev Tanımı & Öğrencinin Süreçteki Görev Tanımı & $\mathbf{f}$ \\
\hline & Soru sorma & Soru sorma & \\
$33.6(\%)$ & -Kısa-kapalı uçlu & -Prosedür soruları & $35(\%)$ \\
$36.6(\%)$ & -Uzun-açık uçlu & -Açıklama soruları & $25(\%)$ \\
$10(\%)$ & Yanıt verme & -Teorik sorular & $25(\%)$ \\
$6.6(\%)$ & Yöneltme & -Pratik sorular & $15(\%)$ \\
$9.9(\%)$ & Övme & Uygulamaların türü & \\
$6.6(\%)$ & Yöneltme & -Doğaçlamalar & $45(\%)$ \\
$25(\%)$ & Yönlendirici olma & -Heykel olma & $10(\%)$ \\
$60(\%)$ & Rehber olma & -Donuk imge & $10(\%)$ \\
& & -Oyunlar & $35(\%)$ \\
\hline
\end{tabular}


Tablo 1 incelendiğinde, öğretmenin süreçteki rolü; çeşitli kategoriler altında incelenmiştir.

Öğretmenin süreçteki rolü: Öğretmenin süreçteki rolü; soru sorma, yöneltme, övme, yönlendirici olma ve rehber olma kategorileri altında incelenmiştir.

Soru sorma: Bu kategori, öğretmen içerik ve işleyişle ilgili, kendi düşüncelerine dayalı olarak, öğrencilere yanıtlayabilecekleri sorular sorduğu ve bu soruların kısa-kapalı uçlu (\% 33.6), uzun açık-uçlu (\%36.6) olduğu belirlenmiştir.

Yöneltme: Süreç içerisinde öğretmenin (\%6.6) öğrencilerini bir amaca ya da hedefe yönelik olarak yönelttiği belirlenmiştir.

Övme: Süreç içerisinde öğretmenin (\%9.9) öğrencilerine verdikleri yanıt sonrasında onları övdüğü tespit edilmiştir.

Yönlendirici olma: Öğretmen çalışmalar kapsamında (\%25) öğrencileri hedeflerine ve amaçlarına ulaşabilmeleri için onlara rehberlik ettiği belirlenmiştir.

Rehber olma: Öğretmenin süreç boyunca sorgulayıcı öğretim yaklaşımına uygun olarak hareket ettiği gözlemlenmiştir. Bu kategori doğrultusunda öğretmen doğrudan öğrenciye bilgi sağlayıcı olmayıp, öğrencilerine (\%60) rehberlik yaptı̆̆g tespit edilmiştir

Öğrencilerin süreçteki rolleri: Öğrencilerin süreçteki rol tanımları; "gerçekleştirilen etkinliklere katılma", "soru sorma" ve "iletişim durumları" ve "yanıt verme" şeklinde kategorize edilmiştir.

Gerçekleştirilen etkinliklere katılma: Öğrencilerin tamamının gerçekleştirilen oyun ve etkinliklere katıldıkları gözlemlenmiştir. Süreç boyunca öğrencilerin tamamının istekli oldukları ve süreçten kopmadıkları gözlemlenmiştir.

Soru sorma: Öğrencilerin süreçte sordukları sorular; (\% 35) prosedür soruları, ( $\% 25)$ açıklama soruları, (\%25) teorik sorular ve (\%15) yaratıcı dramaya ilişkin sorular şeklinde olduğu belirlenmiştir.

Yanıt verme: Çalışma sürecinde öğrencilerin tamamının $(n=6)$, öğretmenlerinin sordukları sorulara yanıt verdikleri gözlemlenmiştir. Bu süreçte; öğrencilerin tamamının gerçekleştirilen etkinlikler, doğaçlamalar, rol oynamalar vb. gibi diğer uygulamalar süresince iyi iletişim kurdukları ve süreç boyunca iyi anlaştıkları gözlemlenmiştir.

Uygulamaların türü: Çalışmalar süresince öğrencilerin doğaçlamalar (\%45), heykel olma (\%10), donuk imge (\%10) ve oyunlar oynadıkları (\%35) belirlenmiştir.

\section{Tartışma ve Sonuç}

$\mathrm{Bu}$ araştırma Maddenin Yapısı ve Özellikleri ünitesi kapsamında gerçekleştirilmiştir. Öğrenciler yaratıcı drama yöntemi ile işlenen derslerin temel amacının; ders konularının daha iyi anlaşılabilmesi ve daha iyi bir düzeye çekebilmesi olduğu ile ilgili görüş bildirmişlerdir. Öğrenciler çalışmalar süresince kullanılan teknikleri beğendiklerini belirtmişlerdir. Özellikle, canlandırma aşamasında sergiledikleri doğaçlamaları ve hikâye yazmalarının sosyal gelişimlerine olumlu katkılar getirdiğini belirtmiştir. Yaratıcı drama etkinliklerinin gerçekleştirildiği ortamın gözlemlenmesinden elde edilen verilerde öğrenci görüşlerini desteklemektedir. 
Öğrenci görüşme verileri, görüşme yapılmayan öğrencilerin günlüklerden elde edilen verilerle uyumlu olduğu görülüştür. Günlüklerden elde edilen verilere göre, özellikle ders başarısı düşük, okul iklimine uyum sağlayamayan ve derse karşı ilgisiz öğrencilerin derste materyal kullanmaktan hoşnut oldukları ve dersin bu şekilde olmasının öğrenmelerine yardımcı olduğunu düşünmektedirler. Ders başarısı düşük olan öğrencilerin uygulamalar sırasında istekli oldukları ve özellikle doğaçlamalarla sürecinde bu öğrencilerin yaratıcı oldukları gözlemlenmiştir. $\mathrm{Bu}$ öğrencilerin değerlendirme aşamalarında ortaya koydukları düşüncelerin ve ürünlerin ve yorumlarının ilgili ünitedeki kazanımları öğrendiklerini ortaya koymuştur.

Görüşmeye katılan öğrenciler ve öğrenci günlüklerinden elde edilen veriler, dersin yaratıcı drama yöntemi sayesinde daha zevkli hale geldiğini, kişiliklerinin sosyal anlamda geliştiğini belirtmişlerdir. Bu araştırma ile benzer sonuçlara sahip araştırmalar bulunmaktadır. Can (2013), beşinci sınıflar ile Işık ve Ses Ünitesi kapsamında yaptığı araştırmada, yaratıcı drama ile ders işlenen deney grubu derslerinin daha eğlenceli ve zevkli olduğu sonucuna ulaşmıştır.

Öğrenciler, yaratıcı drama yöntemi sayesinde öğrendikleri kavramları kullanarak fen ve teknoloji derslerinin diğer konularındaki kavramlarla ilişki kurduklarını belirtmiş̧lerdir. Yaratıcı dramanın yöntem olarak kullanıldığı bu araştırmada öğrencilerin fen ve teknoloji ders başarılarının artış göstermesi de ortaya konulan diğer önemli bir sonuçtur. Uygulamalar esnasında ders başarıları arttığı görüşünü ortaya koyan öğrencilerin özelikle ders süreçlerinde, derse karşı daha fazla katılım gösterdikleri görüşme verilerini destekleyen bir sonuçtur. Bu araştırmanın sonuçları ile benzerlik gösteren çalışmalar mevcuttur. Tuncel (2009), yaptığı araştırmasında, yaratıcı drama yöntemi ile işlenen fen ve teknoloji dersinin 6. Sınıf Maddenin Tanecikli Yapısı ünitesinde, ders başarısının deney grubu öğrencileri lehine çıktığı sonucuna ulaşmıştır. Bunun yanında deney grubu öğrencilerinin yaratıcı drama yöntemi ile ișlenen fen derslerinden keyif aldıkları ve dersi eğlenceli buldukları sonucuna ulaşmıştır. Teker (2009), yaptığı araştırmada yaratıcı drama ile işlenen fen ve teknoloji derslerini öğrencilerin daha iyi anladıklarını, öğrenmelerin kalıcı olduğunu, araştırma isteklerinin arttığını, dersten daha fazla keyif almaya başladıklarını, eğlenerek öğrendiklerini ve derse olan motivasyonlarının arttı̆gı sonucuna ulaşmıştır. Kahyaoğlu, Yavuzer ve Aydede (2010), Isı ve Isının Maddedeki Yolculuğu isimli ünitesi kapsamında yaptıkları araştırmada, yaratıcı drama yönteminin bazı konuların öğretiminde diğer yöntemlere göre daha etkili olduğunu ortaya koymuşlardır. Bu araştırmada da benzer sonuçlara ulaşılmıştır. Gerek gözlem verileri, gerekse görüşme ve gülüklerden elde edilen veriler; yaratıcı drama yöntemi ile işlenen fen ve teknoloji derslerini öğrencilerin sevdikleri, derste eğlendikleri, derse olan ilgilerinin arttığını ve derse katılımlarının daha fazla olduğu belirlenmiştir. $\mathrm{Bu}$ açıdan düşünüldüğünde yaratıcı dramanın araştırma kapsamındaki konuların öğretilmesi üzerine pozitif etkileri olduğu söylenebilir.

Yapılan görüşmelerden, günlüklerden ve gözlemlerden elde edilen veriler, yaratıcı drama atölyelerine katılım sonucu, öğrencilerin fen ve teknoloji sınavlarından aldıkları puanlarda ve derse katılımlarda artışlar olduğu sonucuna ulaşılmıştır.

Görüşme yapılan katılımcıların tamamına yakını yaratıcı drama yönteminin diğer dersler ile ilişkili olduğunu ve yaratıcı drama uygulamalarının diğer derslerde de kullanılmasını düşündükleri göz önüne alındığında; diğer derslerin ünitelerinde yer alan kazanımlarda yaratıcı dramanın kullanılmasının öğrencilere olumlu yönde yansıyacağı sonucuna ulaşılabilir. Bu sonucu, öğrencilerin günlüklerinden elde edilen verilerde desteklemektedir. Yaratıcı dramanın diğer derslerde kullanılması öğrencilerin derslere olan ilgilerine ve katılımlarına pozitif etki yapması beklenebilir. 
Bu araştırmada, öğretmenin yaratıcı drama çalışmaları süresince öğrencilerine rehberlik ettiğ ve onları yönergeler ile doğru bir şekilde sürece uyum sağlamalarını ortaya koyduğu belirlenmiştir. Bu açıdan düşünüldüğünde, bu öğretmeninin ders sürecindeki rolünün, MEB, 2005 Fen ve Teknoloji Dersi Öğretim Programı ve 2013 Fen Bilimleri Dersi Öğretim Programında, öğretmenlerin süreçte sahip olmaları beklenen roller ile uyumlu olduğu söylenebilir. Bu kapsamda düşünüldüğünde, yaratıcı drama atölyelerini sürdüren öğretmenin süreçte rehber olarak öğrencileri ile dersi yürütmesinin doğru olduğu görülmektedir. Bunun yanında öğrencilerinde çalışmalar süresince öğretmenlerinin verdiği yönergelere uygun davrandıkları ve ilgili konular ile ilgili olarak doğaçlamalar sürecinde yaratıcı ürünler ortaya koydukları belirlenmiştir.

\section{Öneriler}

Yaratıcı dramanın yöntem olarak, ortaokulun farklı sınıf seviyelerinde bulunan şubelerde maddenin yapısı ve tanecikli yapısı ünitelerini ilgilendiren kazanımların öğretiminde de kullanılması ve bu kapsamda özgün etkinliklerin hazırlanması önerilebilir.

Yaratıcı drama yönteminin öğrenciler üzerinde olumlu etkiler bıraktığı göz önüne alındığında fen bilimleri dersini sevmeyen, derse karşı olumsuz tutuma sahip olan ve ders başarısı düşük olan öğrencileri derse karşı pozitif yönde güdüleme ve bağlamında bu öğrencilerin olduğu sınıflarda yaratıcı dramanın yöntem olarak yoğun biçimde kullanılması önerilebilir.

Fen bilimleri öğretmenlerinin derslerde kendilerinin geliştirebilecekleri etkinlikleri hazırlayabilecek şekilde yaratıcı drama eğitimini, yaratıcı drama alanında uzmanlaşmış kuruluşlardan ve uzmanlardan almaları, teşvik edilebilir.

\section{Kaynakça}

Açı1, E. (2012). Fen eğitiminde yaratıcı drama yönteminin ilköğretim öğrencilerinin bilimsel yaratıcılıklarına ve akademik başarılarına etkisi. Yüksek Lisans Tezi, Dokuz Eylül Üniversitesi, Sosyal Bilimler Enstitüsü, İzmir.

Ayas, A. Ve Özmen H. (2002). Lise kimya öğrencilerinin maddenin tanecikli yapısı kavramını anlama seviyelerine ilişkin bir çalışma. Boğaziçi Üniversitesi Eğitim Dergisi, 19(2), 45-60.

Adıgüzel, Ö. (2012). Eğitimde yaratıcı drama. Ankara: Naturel Yayınc1lı.

Can, T. B., (2013). The effects of using creative drama in science education on students' achievements and scientific process skills. Elementary Education Online, 12(1), 120-131.

Creswell J. W. (2007). Qualitative inquiry research design. Choosing among five approaches, Thousand Oaks,California: Sage Publications.

Çepni, S. (2007). Kuramdan uygulamaya fen ve teknoloji öğretimi (9. Baskl). Ankara: Pegem A yayıncılık.

Çopur, T. (2014). Mekanik konularının öğretiminde yaratıcı drama yönteminin uygulanması ve değerlendirilmesi. Doktora Tezi, Gazi Üniversitesi, Eğitim Bilimleri Enstitüsü, Ankara.

Hatch, J.A. (2002). Doing qualitative research in education settings. Albany: State University of New York Press.

İdin, Ş. (2015). Zenginleştirilmiş eğitim uygulamalarinin 7. sinif öğrencilerinin fen bilimleri ders başarilari tutumlari ve kaliciliğa etkisi. Doktora Tezi, Hacettepe Üniversitesi, Eğitim Bilimleri Enstitüsü, Ankara. 
Maddenin Yapısı ve Özellikleri Ünitesinde Yaratıcı Drama Yönteminin Kullanılması Üzerine Bir Uygulama Çalışması ve Öğrenci Görüşleri

Kahyaoğlu, H., Yavuzer, Y. ve Aydede M.N. (2010). Fen bilgisi dersinin öğretiminde yaratıcı drama yönteminin akademik başarıya etkisi, Türk Ĕgitim Bilimleri Dergisi, 8 (3), 741-758.

MEB., (2000). İlköğretim okulu fen bilgisi dersi öğretim programı. Ankara: Milli Eğitim Basımevi.

MEB., (2005). İlköğretim fen ve teknoloji dersi ögretim programı. Ankara: Milli Eğitim Basımevi.

MEB., (2012). Ortaokul ve imam hatip ortaokulu drama dersi (5 ve 6. Sinıflar) ögretim programı. Ankara: Milli Eğitim Basımevi.

MEB., (2013). İlköğretim kurumları fen bilimleri dersi (3,4,5,6,7 ve 8. Sinıflar) öğretim programı. Ankara: Milli Eğitim Basımevi.

MEB., (2016). PISA Nedir? [Çevrim-içi: http://pisa.meb.gov.tr/?page_id=18], Erişim tarihi: 28.04.2016.

MEB., (2016). Öğretmenlik mesleği genel yeterlikleri. [Çevrim-içi: http://otmg.meb.gov.tr/belgeler/ogretmen_yeterlikleri_kitabi $/ \% \mathrm{C} 3 \% 96 \% \mathrm{C} 4 \% 9$ Fretmen_Yeterlikleri_Kitab $\% \mathrm{C} 4 \% \mathrm{~B} 1$ genel_yeterlikler_par\% $\%$ C3\%A7a_2.pdf], Erişim tarihi: 16.06.2016.

Merriam, S.B. (2009). Qualitative research. a guide to design and implementation (2nd ed.). San Francisco: Jossey-Bass

Miles, M. B., ve Huberman, A. M. (1994). Qualitative data analysis: An expanded sourcebook (2nd ed.). Thousand Oaks, California: Sage Publications.

Miller, D.L. (1997). One strategy for assessing the trustworthiness of qualitative research: Operationality the external audit. Dissertation Abstract International, (ERIC No. 4112668)

National Research Council (NRC), 1996. National science education standards. Washington, DC: Natioanal Academy Pres.

Shenton, A. (2004). Strategies for ensuring trustworthiness in qualitative research projects. Education for Information, 22, 63-75.

Özdemir, P. ve Üstündağ, T. (2007). Fen ve teknoloji alanındaki ünlü bilim adamlarına ilişkin yaratıcı drama eğitim programı. İlköğretim Online Dergisi, 6(2), 226-233.

Teker, E. (2009). Fen ve teknoloji ögretiminde yaratıcı drama yönteminin kullanılmasının ilköğretim ögrrencilerinin fenne yönelik görüşlerine ve çevre ile ilgili problem durumlara etkisi. Yüksek Lisans Tezi, Abant İzzet Baysal Üniversitesi, Sosyal Bilimler Enstitüsü, Bolu.

Tuncel, S. (2009). Illköğretim 6. sinıf fen ve teknoloji dersinde maddenin tanecikli yapısı ünitesinin yaratıcl drama ile ögretiminin öğrencilerin başarısına etkisi. Yüksek Lisans Tezi, Selçuk Üniversitesi, Fen Bilimleri Enstitüsü, Konya.

Ürek, R.Ö. ve Tarhan, L. (2005). Kovalent bağlar konusundaki kavram yanılgılarının giderilmesinde yap1landırmacılığa dayalı bir aktif öğrenme uygulaması. Hacettepe Üniversitesi Eğitim Fakültesi Dergisi, 28, $168-177$.

Üstündağ, T. (1996). Yaratıcı dramanın üç boyutu. Yaşadıkça Ĕ̆itim, 46, 19-23.

Üstündağ, T. (2010). Yaratıcı drama öğretmenimin günlüğ̈̈. (10.bs.). Ankara: PegemA Yayıncılık.

Yağmur, (2010). 7.Sinıf fen ve teknoloji dersinin yaratıcı drama destekli işlenmesinin eleştirel düşünme becerisi ve başarı üzerine etkisi. Yüksek Lisans Tezi, Sakarya Üniversitesi, Fen Bilimleri Enstitüsü, Sakarya.

Yıldırım A., \& Şimşek H. (2008). Sosyal bilimlerde nitel araştırma yöntemleri (7. Baskı). Ankara: Seçkin Yayıncillk.

Yıldırım, K. (2010). Nitel araştırmalarda niteliği artırma. İlköğretim Online, 9(1), 79-92.

Yıldırım, A. ve Şimşek, H. (2011). Sosyal bilimlerde nitel araştırma yöntemleri. Ankara: Seçkin Yayıncılık.

YÖK, (2016). Ulusal Tez Merkezi. [Çevrim-içi: https://tez.yok.gov.tr/UlusalTezMerkezi/tezSorguSonucYeni. jsp], Erişim tarihi: 02.05.2016. 


\section{EK-1: Örnek Yaratıcı Drama Ders Planı}

Ders: Fen ve Teknoloji

Ünite: Maddenin Yapısı ve Özellikleri

Konu: Elementler ve Elementlerin Sembolleri

Sinıf: $7 / \mathrm{A}$

Grup: 7. Sinıfta öğrenim gören 21 öğrenci

Süre: 2 ders saati $\left(40^{\prime}+40^{\prime}\right)$

Mekân: 7/A Şubesi (40 $\mathrm{m}^{2}$ genişlikte, ilgili mekân yaratıcı drama atölyesinin gerçekleştirilmesi için minderler, güvenlik önlemleri vd. gibi araç gereçler için mekân yeniden düzenlenmiştir.)

Teknikler: Rol Oynama, Doğaçlama.

Araç Gereçler: Bilgisayar, CD, Kâğıt, Karton,

\section{Kazanımlar:}

1.1.Model üzerinde, bir elementin bütün atomlarının aynı olduğunu fark eder.

1.2.Model ve şekilleri kullanarak farklı elementlerin atomlarının farklı olduğunu sezer.

\section{SÜREÇ}

\section{Hazırlık-Isınma}

\section{Etkinlik}

Katılımcılardan müzik eşliğinde mekânda serbestçe yürümeleri istenir. Bir süre sonra onlardan herhangi bir atomu düşünmeleri istenir. Burada katılımcılara kâğıt kalem verilir. Onlardan istedikleri atomları çizmeleri istenir. Hayallerindeki atomları kalemleri ve farklı renklerdeki boya kalemlerini kullanarak kâğıtlara çizmeleri istenir.

\section{Etkinlik}

Katılımcılarla kulaktan kulağa oyunu oynanır. Bu oyunun oynanması için katılımcılar iki gruba ayrılırlar. Her grup kendi içinde öndeki kişinin sırtını görecek şekilde oturur. Bir gruba "aynı tür atomlar" sözcüğü diğer gruba da "farklı tür atomlar” sözcüğü verilir. Grubun ilk üyesi bu sözcüğü arkasındaki kişiye diğer grup üyeleri görmeden beden dilini kullanarak anlatır, o üye anladığını diğerine anlatır ve bu şekilde devam edilerek en son kişiye kadar gelinir. Etkinliği en doğru ve hızlı bitiren grup birinci olur. Bu oyun "Atomik yapılı element" ve "molekül yapılı element" söz öbekleri verilerek bir tur daha oynatılir.

\section{Ara Değerlendirme:}

Katılımcılardan duygu ve düşüncelerini grupla paylaşmaları istenir.

\section{Canlandırma}

\section{Etkinlik}

Katılımcılar birden dörde kadar sayarlar. Aynı rakamları söyleyen katılımcılar aynı gruplarda olacak şekilde dağılırlar. Katılımcılara bilgi kartları dağıtılır. Bilgi kartlarında "atomik yapılı 
element", "molekül yapılı element", kavramlarını karşılayan aynı ve farklı elementlere ait bilgi kartları dağıtılır. Katılımcılardan ikili gruplar oluşturmaları istenir. Verilen bilgi kartlarına göre doğaçlamalar yapmaları istenir.

\section{Bilgi Kartı:}

Karbon (C) : Atomik yapıda bir elementtir. Tek başına hareket eder. Atomları kendinden başka hiçbir atoma benzemez.

Oksijen (O2): Sembolü “O” dur. Molekül yapıda bir elementtir. Yaşam için gereklidir. Atomları birleşerek Oksijen elementini oluştururlar.

Hidrojen (H2): Sembolü "H" dir. Molekül yapılı bir elementtir. Yaşam için gereklidir. Atomları birleşerek Hidrojen elementini oluştururlar.

Sodyum (Na): Sembolü "Na” dır. Atomik yapılı bir elementtir. Günlük hayatta birçok yerde kullanılır. Atomları birleşerek Sodyum elementini oluştururlar.

\section{Değerlendirme}

\section{Etkinlik}

Katılımcılardan duygu ve düşüncelerini grupla paylaşmaları istenir. Atölye sonunda elde edilen kazanımlarla ilgili görüşler üzerinde konuşulur. Katılımcılara günlüklerine yazacakları görüşlerini unutmamaları anımsatılarak, atölye tamamlanır. 


\section{EK-2: GÖRÜŞME FORMU}

Okul:

Tarih:

Saat:

Görüşmeci:

\section{GİRIŞ}

Merhaba, benim adım ve orta okulunda fen ve teknoloji öğretmeni olarak görev yapmaktayım. Maddenin Yapısı ve Özellikleri ünitesi kapsamında, dersi yaratıcı drama yöntemi ile işlememizin fen ve teknoloji ders başarılarınız üzerine olan etkilerini ortaya çıkarmak için bu araştırmayı yapmaktayım. Bu araştırmada ortaya çıkacak sonuçları, bundan sonra yapilacak olan fen ve teknoloji derslerinin daha verimli ve etkin bir şekilde yürütülmesine katkılar getireceğini umuyorum. Bu nedenden dolayı, katıldığınız yaratıcı drama atölyesi ile ilgili düşüncelerinizi ve beklentilerinizi öğrenmek istiyorum. Görüşme süresince bana söyleyeceğiniz tüm sözleriniz gizlidir. Bu bilgilerin araştırmacılar dışında kimsenin görmesi olanaklı değildir. Araştırma sonuçlarını yazarken, isminizi kesinlikle raporuma yansıtmayacağıma emin olmanızı isterim. Görüşmeye başlamadan önce, bu söylediklerimle ilgili olarak belirtmek istediğiniz bir düşünceniz ya da sormak istediğiniz herhangi bir sorunuz var mı? Görüşmeyi müsaadeniz olursa kaydetmek istiyorum. Bunun sizce bir sakıncası var mı? Bu görüşmenin yaklaşı olarak 45 dakika süreceğini tahmin ediyorum. İzin verirseniz sorularıma başlamak istiyorum.

\section{Görüşme Soruları}

Öğrenciyi Tanımaya Yönelik Sorular

1)Kendinizi kısaca tanıtır misınız?

Kaçıncı sınıfta öğrenim görmektesiniz?

Kaç yaşındasınız?

Daha önce sınıf tekrarı yaptınız mı?

1) Okulunuzda uygulanan yaratıcı drama çalışmalarının hangilerine katıldınız?

Hangi ders kapsamında?

Hangi ünitede?

Hangi konuda?

Ne zaman?

Ne kadar süreyle?

2) Katıldığınız yaratıcı drama çalışmalarının amacı sizce neydi?

Amaç açıklandı mı?

Amaç tüm öğrenciler tarafından aynı şekilde anlaşıldı mı?

3) Sizce yaratıcı drama ile işlenen derslerin temel amacı ne olmalıdır?

Öğrenci yönünden?

Öğretmen yönünden?

Okul yönünden? 
Öğrenci veli/velileri yönünden?

4) Katıldığınız yaratıcı drama çalışmalarında kullanılan teknikleri nasıl buluyorsunuz?

Sizlerin etkin olmanızı sağlama?

Sizlerin yardımlaşmalarınızı sağlama?

Sizlerin iletişim kurmanızı sağlama?

Sizlerin diğer dersler ile ilişki kurabilmenizi sağlama?

5) Yaratıcı drama için kullandığınız materyalleri nasıl değerlendiriyorsunuz?

6) Yaratıcı drama atölyesindeki çalışmalarda öğrendiğiniz yeni bilgileri;

Fen ve Teknoloji dersinde?

Fen ve Teknoloji Sinavlarında?

Fen ve Teknoloji ders içi etkinliklerde?

Doğal hayatta?

Nasıl değerlendiriyorsunuz? Bu bilgilerden nasıl yararlanıyorsunuz?

7) Fen ve Teknoloji ders başarınız, yaratıcı drama yöntemi ile ders konularını işledikten sonra;

Fen ve Teknoloji dersinde sınıf içindeki performansınız kapsamında;

Fen ve Teknoloji Dersi yazılıları kapsamında,

Diğer derslerin değerlendirmeleri ile ilişkili olarak bu kapsamda;

Herhangi bir değişim oldu mu? Olduysa bu değişimlerden bahseder misiniz.?

8) Yaratıcı drama yöntemi ile ders işlemenin diğer derslere olan etkilerini nasıl değerlendiriyorsunuz?

9) Sizin, yaratıcı drama yöntemi ve bu şekilde ders işleme ile ilgili belirtmek istediğiniz herhangi bir düşünceniz varsa dinleyebilirim?

Büyük bir sabırla beni dinleyerek sorularıma yanıt verdiğiniz için çok teşekkürler. 


\section{EK-3: Maddenin Yapısı ve Özellikleri Ünitesi Kazanımları}

1.Model üzerinde, bir elementin bütün atomlarının aynı olduğunu fark eder .

2.Model ve şekilleri kullanarak farklı elementlerin atomlarının farklı olduğunu sezer .

3.Periyodik sistemdeki ilk 20 elementi ve günlük hayatta karşılaştığı yaygın element isimlerini listeler.

4.Elementleri sembollerle göstermenin bilimsel iletişimi kolaylaştırdığını fark eder.

5.İlk 20 elementin ve yaygın elementlerin sembolleri verildiğinde isimlerini, isimleri verildiğinde sembollerini belirtir

6.Maddeyi oluşturan atomları, bağlı atomları ve molekülleri model ve temsili resim üzerinde gösterir; bağ ile atomların veya moleküllerin uzaklığı-yakınlığı arasında ilişki kurar .

7.Sürtme ile elektriklenme olayına dayanarak atomun kendinden daha basit öğelerden oluştuğu çıkarımını yapar.

8.Atomun çekirdeğini, çekirdeğin temel parçacıklarını ve elektronları temsili resimler üzerinde gösterir.

9.Nötr atomlarda, proton ve elektron sayıları arasında ilişki kurar.

10.Elektronu, protonu ve nötronu kütle ve yük açısından karşılaştırır; atomun kütlesinin, yaklaşık olarak proton ve nötron kütleleri toplamı olduğu sonucuna ulaşır.

11.Dış katmanında 8 elektron bulunduran atomların elektron alıp-vermeye yatkın olmadığını (kararlı olduğunu) belirtir.

12.Elektron almaya veya vermeye yatkın atomları belirler.

13.Bir atomun, katman-elektron diziliminden çıkarak kaç elektron vereceğini veya alacağını tahmin eder.

14.Atomların elektron verdiğinde pozitif (+), elektron aldığında ise negatif (-) yük ile yüklendiği çıkarımını yapar.

15.Yüklü atomları "iyon” olarak adlandırır.

16.Pozitif yüklü iyonları "katyon”, negatif yüklü iyonları ise "anyon” olarak adlandırır.

17.Çok atomlu yaygın iyonların ad ve formüllerini bilir.

18.Farklı atomların bir araya gelerek yeni maddeler oluşturabileceğini fark eder .

19.Her bileşikte en az iki element bulunduğunu fark eder.

20.Molekül yapılı maddelerin model veya resmi üzerinde atomları ve molekülleri gösterir

21.Karışımlarda birden çok element veya bileşik bulunduğunu fark eder .

22.Heterojen karışım (adi karışım) ile homojen karışım (çözelti) arasındaki farkı açıklar.

23.Katı, sıvı ve gaz maddelerin sıvılardaki çözeltilerine örnekler verir. 